\title{
Six Sigma and Lean for Enhanced Process Value Chain
}

\author{
Maryam Zulfiqar \\ University of the West of Scotland \\ School of Computing, Engineering and Physical Sciences \\ maryamzulfiqar956@gmail.com
}

\begin{abstract}
Purpose This research highlight the different aspects of implementing lean and six-sigma approach, their contrasting features and integration in manufacturing organizations. Methodology Qualitative research method has been used to conduct this research as the defined period of time for the research was limited. This method was pertinent for the deep analysis of literature and case studies of concerned approaches. It helped to conduct the research in a subjective manner. The use of secondary data saved time from preparing the questionnaires or surveys also the ethical approval to conduct research was not required. Descriptive feature of qualitative research was germane to gather substantial information of related topic from different legitimate resources. For the collected data analysis, Deductive scientific approach has been applied. This research does not make use of any statistical tools for data analysis.
\end{abstract}

Findings Literature studies reveal that Lean Six Sigma has been most frequently used in service organization in comparison of manufacturing industries. It has been observed that the Implementation of Lean Six Sigma gave an amalgam of advantages of both approaches when deployed together in terms of cutting down the cost of production, decreasing process variations, lower process waste and effective resource management. Value These findings shall be helpful for the practitioners who plan to implement LSS in manufacturing organizations.

Limitations This research was limited by few factors as the time-frame was not enough to cover up every aspect of the selected topic. Moreover, six case studies were found not to be enough to generalize the model for Lean Six Sigma implementation because there is a possibility of a manufacturing organization of different nature that may not be covered in the research. Furthermore, the concluded concepts shall be applicable only for manufacturing organizations. Adding to this, the research methodology was not enough to add up to the data collection skills of the researcher.

Future Research For future studies there is a need to fill the research gap by using quantitative research method to analyze the impact of Lean and Six Sigma integration on process value chain. Future researchers can also take up the service organizations as a subject matter for an extensive research.

Keywords Lean; Six Sigma; Integration; Manufacturing Industries 


\subsection{Introduction}

\subsection{Six sigma}

It has been observed that from last two decades, Six Sigma and the Lean approach are increasing in popularity. Motorola Corporation first introduced Six Sigma and later on, the American companies started practicing it. Six-sigma focuses on the reduction of variations within the process chain. Apart from highlighting the variations in the process, six-sigma is also a useful problem -solving methodology. It follows the DMAIC (Define, Measure, Analyse, Improve, and Control) framework for the implementation that helps to trace out the root cause of the problem (Brue and Howes, 2005) and reduce variation. Variation reduction helps to reduce the production cost and time, which in return adds to the profit of the business. Furthermore, the six sigma application helps the detailed understanding of the process from employees to the managerial level and also gives an opportunity to the operators to use the statistical principles in order to evaluate the areas of the variation in the process (Dale et al., 2007).

\subsection{Lean}

On the other hand, the Lean approach was initiated by Toyota in Japan and spread to Western corporations. The driving force behind Japanese companies adopting this approach was the insufficiency of natural resources (Sheridan, 2000). Lean strategy is mostly referred to as a cost reduction mechanism (Achanga, 2006 and Bicheno, 2004). Lean approach implementation helps an organization to compete with other organizations in the market. It helps to eliminate or reduce the steps in the process that are not value adding within the process chain. So the removal of the non-value adding steps helps to increase the overall efficiency of the process chain which in turn adds up to the profit of the organization (Motwani, 2003). An organization can efficiently get positive results of Lean strategy without affecting any positive activity of the process chain. This can only be achieved by producing exactly the amount, which is required, and on the time when it is required (Kannan and Tan, 2005, Monden, 1981). Moreover, lean approach aims to minimize the waste from all the areas of process chain rather than focussing on one particular step of an activity (Womack and Jones, 1994). This encourages the use of process mapping in order to understand and analyse the process activities so that the non-value adding activities could be analysed and removed from the process. In terms of lean approach, it is referred as Value Stream Mapping (Doolen, 2006).

\subsection{Lean Six Sigma}

The integrated methodology of Lean and six sigma is able to give combined benefits of both strategies. (Antony, Bendell, 2006) Literature studies reveal that the first integration of Lean and Six Sigma was conducted in USA at George Group in 1986. The positives outcomes of LSS implementation made it popular among manufacturing as well as service organizations around the globe (Chen and Lyu, 2009)

In order to study and understand the real life cases on the implementation of lean, Six Sigma and Lean Six Sigma six case studies have been narrated. The implementation of six sigma by Motorola is one of the most famous and earliest cases, which has been referenced in this research project. Adding to this, a Thai Gloves Manufacturing organization implementing six sigma in its manufacturing process has been described. Moreover, two case studies regarding the implementation of Lean approach have been mentioned to understand the 


\section{$8^{\text {th }}$ INTERNATIONAL CONFERENCE ON LEAN SIX SIGMA}

strategy. Along with this, two case studies have explained the practice of integration of Lean Six Sigma.

\subsection{Literature Review}

\subsection{Six sigma origin}

In 1986 an engineer at Motorola, developed and suggested the six-sigma approach for implementation. It was proposed with the objective of improving quality and the reducing the number of defects in cars being manufactured. (Eckes, 2000). By the deployment of six sigma the CEO of Motorola Bob Galvin, was highly impressed by its outcomes, which not only improved the quality of the products of Motorola but also gave positive outcomes in overall performance and profit ratio. Therefore, Motorola started to implement six sigma strategy across the organization with the focus on its manufacturing and processing area. It was observed that the six sigma plan was highly fruitful for Motorola which was later identified by the calculation of its number of defects. Calculations revealed that the numbers of defects were reduced by 94\% between 1987 and 1993 (Godfrey, 2002). It has been estimated that in the recent years, the six sigma strategy has been widely spread across the manufacturing as well as the service organizations. (Chakraborty, 2006) The beneficial features and outcomes of reducing time, cost and improving quality has made it popular in the market. Six sigma is not only being practiced by small companies, instead it has been deployed by large and medium sized organizations as well. (Folaron, 2003).

\subsection{Six-sigma Implementation}

The DMAIC framework has certain tollgates between its steps. These represent the activity of staff where the project team members show their task to the managers and the owners of the assigned process. Tollgates are such checkpoints which helps to analyse the project that either everything is on track and going well or not. These provide an opportunity to evaluate and calibrate the process on the continual basis.

The first step of (DMAIC) define involves the focus on objectives and goals of the project, it demands the enlisting of the project boundaries, tracing out the customer demands and expectations and also allocate the team members with their specific roles and responsibilities in the process. (Gijo et al, 2011).

The second step of DMAIC is "Measure" This phase of DMAIC helps to evaluate the current performance of the process. It focuses on measuring the quality of products, cost of production along with throughput or the cycle time of the process. (Omachonu and Ross, 2004). The evaluation and close monitoring of the current process helps to implement the improvements. The process capability mapping helps to assess that the exact position of the performance level with respect to the organization goals and objectives level. (Stamatis, 2004). The third phase i.e. Analyse, focuses in determining the root cause of the problem associated with the process under analysis. It enables the employees to answer the questions like why a particular issue has occurred and gives the comparative analysis with better opportunities that can be implemented in order to overcome the problem. (Adams, Gupta, Wilson, C.E, 2003) The fourth phase "Improve" emphasizes on the use of experimentation and statistical techniques in order to implement the suggested opportunities (put forth in third phase). This will help to produce better results by comparatively improving the quality or by solving the focused problem in the process. (Omachonu, Ross, 2004). The last phase of DMAIC demands to pay attention towards specific controls measures, which are needed to be practiced in order to keep a smooth flow of the ongoing process. The process improvements, which are 


\section{$8^{\text {th }}$ INTERNATIONAL CONFERENCE ON LEAN SIX SIGMA}

monitored, required be well documenting and institutionalising for their further implementation in the process. (Omachonu, Ross, 2004). The objective of the control phase is accomplishing all the remaining tasks of the project and handing over the improved process to the process with certain guidelines that are required to be performed at intervals.

\subsection{Lean Approach}

Literature studies explore that lean approach has even earlier history than six sigma. The foundational theme of the lean approach has roots back to W.F.Taylor and H.Ford in 1911. (Čiarnienè, Vienažindienè, 2012) They introduced an effective production system at a manufacturing plant at Highland Park in 1913. This system was consisted of the set of activities and certain tools that incredibly increased the speed of production and also increased the consistency of the production system.

Lean implementation is based upon two objectives that is the elimination or reduction of waste and enhancing the process values by promoting value-adding steps (Spear, 2004). Most prominently, Value Stream Mapping is done to conduct Lean approach (Singh and Sharma, 2009). Lean Implementation strategy was explained under the light of five principle steps of implementation. (Womack, 2002, Hopp and Spearman, 2004; Pettersen, 2009). These are mentioned as:

$>$ Defining customer and focussing value

$>$ Tracing and identifying Process Value Stream

$>$ Generating a process flow after eliminating waste

$>$ Responding to the customer Pull

$>$ Promoting and pursuing perfection

\subsection{Contrasting features of lean and six sigma}

(George, 2004) put forward the major difference between these two approaches. According to him six sigma approach aims to produce products with zero defects while the lean aims to improve the flow of process chain and focuses on the waste reduction or elimination. Both approaches operate under the same objective of increasing the internal and external customer satisfaction with the strategy of using lesser amount of resources (Hellsten and Klefsjo, 2000).

\subsection{Lean and six sigma integration}

Although the exclusive benefits of six sigma and lean are beneficial for a range of organization but the combination of these two approaches gives an opportunity to get benefits of both strategies together (Ferguson, 2007). There is no defined or standardized procedure to implement LSS. This adds to the flexibility of approach that it can be deployed in any kind of organization. (Pande et al., Neuman, \& Cavanagh, 2000; Cross, 2007; Dreachslin, 2007; Froehling, 2008). Among the variety of methods, the most commonly used is DMAIC approach for LSS. It gives a basis of statistical tools for the application of lean tools, which are mostly analytical in nature. Lean toolkit is applied at each phase of DMAIC framework. Because of this flexible framework for implementation, it was practiced by both manufacturing as well as service organizations. General Electric is among the pioneers of applying LSS. The high rate of its achievement in different departments encouraged its implementation by other companies as well. (Kamenski, 2011). Afterwards Xerox also made a remarkable achievement by increasing the profit ratio through LSS. Adding to this, Caterpillar Company developed a strategic approach in order to improve its business profit; this strategy was also principally 
based on LSS. Moreover, a Korean steel maker organization named BOSCO; popped into the global market by providing improved quality steel and services to its customers. In addition to it a Mexican organization which has a business of manufacturing of equipment, it improved its process operations through LSS implementation (Fornari and Maszle, 2004).

In 2005 (Arnheiter, Maleyeff 2005) explained the intersection of lean and six sigma that this strategy would help to maximize the value-added activities in the process. It also described the focus of the managerial business decisions to be based on the customer demands.

Figure 1 customer view point

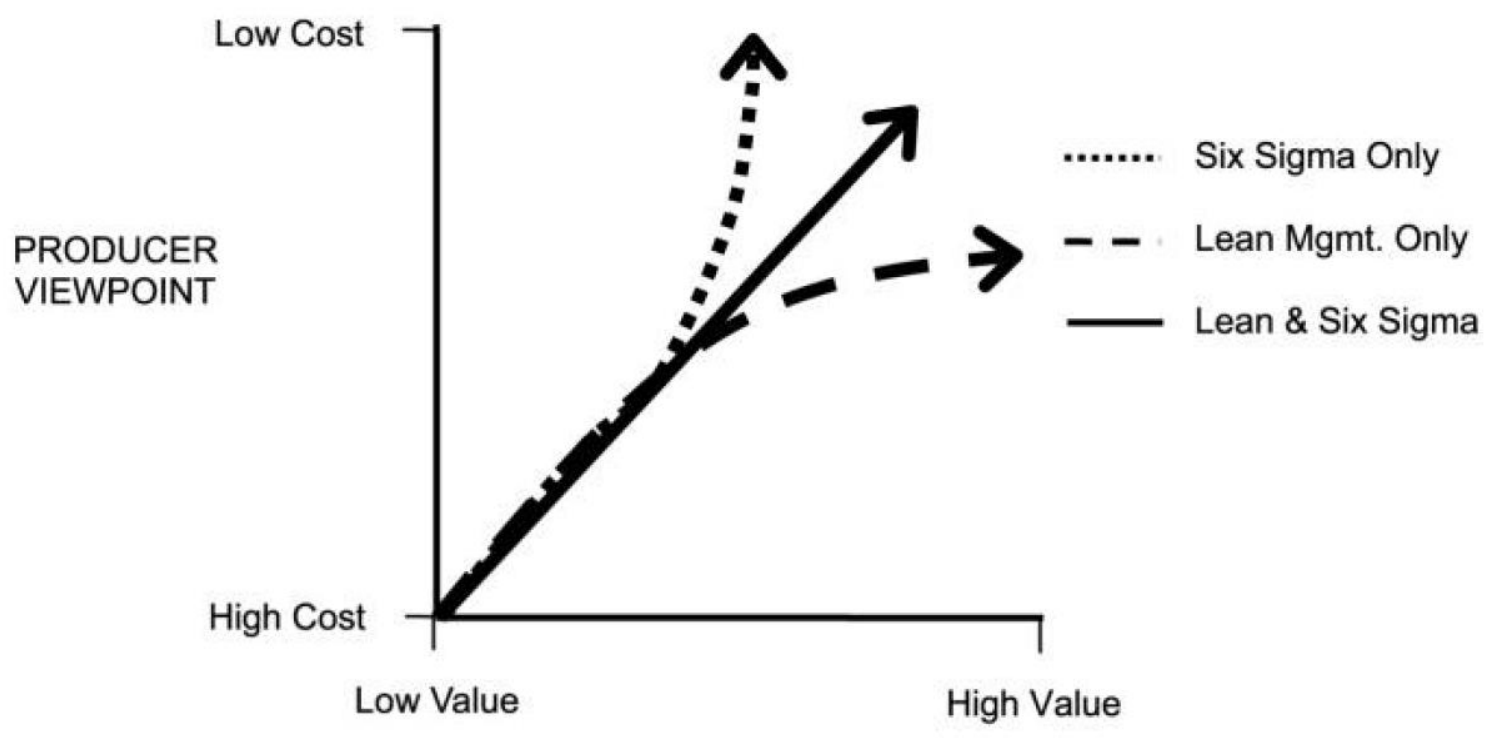

Source: Arnheiter, Maleyeff 2005

In 2018, A Lean Six Sigma framework was presented to enhance the competitiveness in selected automotive component manufacturing organisations.

\subsection{Methodology}

Keeping in view the features of both research methods, qualitative research method has been used to conduct this research. The selection of this method was made on the following basis:

$>$ The defined period for the research was limited so it was suitable to select qualitative method.

$>$ This method was helpful for the deep analysis of literature and case studies of concerned approaches.

$>$ It helped to conduct the research in a subjective manner.

$>$ The use of secondary data saved time from preparing the questionnaires or surveys and there was no need to for ethical approval.

$>$ Descriptive feature of qualitative research was helpful for the gather of large information of related topic from different authentic resources.

$>$ No specific expertise was required for data analysis as this method does not make use of statistical tools. 


\subsection{Literature study}

The basic source of information for the execution of this project is secondary data through literature review and deep analysis of case studies. A systematic literature has become a basic scientific activity for conducting research. (Okoli and Schabram, 2010). In this research project, the systematic literature review has been conducted to establish a theme, which is able to support the aims and objectives of the research. The basic processes and steps of literature review conduction are mentioned as

$>$ Research questions and objectives were identified after analysing the gaps of knowledge in literature. The present significance of lean and sigma approach in organizations around the globe and its widening future triggered to select it as a research project topic.

$>$ The research protocol involved the study of the future scope of Six Sigma, Lean and their integration, strategies of implementation, assessment and critical analysis of data collected and so on. These steps and protocol has been followed during systematic study of literature.

$>$ While deciding about the exclusion and inclusion research articles, the latest ones has been selected. The unrelated articles or any other research material has been excluded to make the research objectives and research view more clear and definite.

$>$ The inclusion of most relevant research papers has helped to establish a theme that shows a strong link with research objectives. There raised a need to include some research papers older than ten years in order to mention the historical background of the approaches.

$>$ Well-known Quality journals and electrical resources has been used in order to make sure that the information mentioned in the project is up to date and is authentic. A list of references has been given to verify or confirm any information mentioned in the project.

$>$ In the selection of articles, which are referenced in research, the quality of article was assessed by considering its score. Impact factor of article also gave an idea about the authenticity of article.

$>$ It is not necessary that each article selected to consider for research shall contain only the relevant information. Therefore, the relevant data was extracted by deep and thorough analysis of literature.

$>$ It was also considered carefully that the reporting of data in research may not change the original piece of information.

\subsection{Scientific approach}

For this research deductive approach has been used. As explained by (Wilson, 2010) that deductive reasoning follows the approach of reaching to a general conclusion by analysing a particular situation. It has been noted that if a normal relationship is applied by certain theory or a thoroughly analysed by certain case study then it can be applied in many cases of that particular kind. In this research, case studies of different organizations have been considered and analysed. Organizations in case studies have explained the method of implementing six sigma, lean and the integration of both approaches which covers up the research objectives to a large extent. Real case analysis has helped to highlight the advantages as well as barriers in the implementation of quality approaches. Therefore, by using deductive reasoning, certain recommendations and conclusions are drawn based on discussed case studies. 


\subsection{Results}

Table 1: key features of case studies

\begin{tabular}{|c|c|c|c|c|c|c|c|}
\hline $\begin{array}{l}\text { Key } \\
\text { features }\end{array}$ & $\begin{array}{l}\text { Company } \\
\text { Background }\end{array}$ & Problem & Focus & Objective & Methodology & $\begin{array}{l}\text { Tools and } \\
\text { techniques }\end{array}$ & Results \\
\hline $\begin{array}{l}\text { Case } \\
\text { study } 1\end{array}$ & $\begin{array}{l}\text { Thai gloves } \\
\text { manufacturing }\end{array}$ & $\begin{array}{l}\text { Stains on gloves } \\
\text { and size variations }\end{array}$ & $\begin{array}{l}\text { Quality } \\
\text { improvement }\end{array}$ & $\begin{array}{l}\text { To reduce gloves } \\
\text { rejection and number } \\
\text { of defects }\end{array}$ & $\begin{array}{l}\text { six sigma } \\
\text { DMAIC } \\
\text { framework }\end{array}$ & $\begin{array}{l}\text { Statistical tools } \\
\text { (ANOVA, } \\
\text { Pareto } \\
\text { analysis) }\end{array}$ & $\begin{array}{l}\text { Six sigma revealed that } 230^{\circ} \mathrm{c} \text { temperature } \\
\text { and } 650 \mathrm{RPM} \text { are the optimum parameters } \\
\text { to get a reduced number of defects, } \\
\text { improved quality and reduced cost. }\end{array}$ \\
\hline $\begin{array}{l}\text { Case } \\
\text { study } 3\end{array}$ & $\begin{array}{l}\text { Crank shaft gear } \\
\text { manufacturing } \\
\text { company in India. }\end{array}$ & $\begin{array}{l}\text { Crank shaft gear } \\
\text { rejection, high } \\
\text { level of inventory, }\end{array}$ & $\begin{array}{l}\text { Process and } \\
\text { quality } \\
\text { improvement }\end{array}$ & $\begin{array}{l}\text { To reduce delivery } \\
\text { delays, process } \\
\text { improvement (to } \\
\text { reduce defects) } \\
\text { decrease and } \\
\text { inventory levels }\end{array}$ & $\begin{array}{l}\text { Lean } \\
\text { Value stream } \\
\text { Mapping }\end{array}$ & $\begin{array}{l}\text { Kanban system } \\
\text { was proposed, } \\
\text { takht time } \\
\text { analysis }\end{array}$ & $\begin{array}{l}\text { The estimated calculations presented that } \\
\text { company was able to reduce its lead time } \\
\text { by } 92.58 \%, 2.17 \% \text { reduction in the process } \\
\text { time and also } 97.1 \% \text { reduction in Work in } \\
\text { Progress time (WIP). Work force } \\
\text { consumption was also expected to be } \\
\text { reduced by } 26.08 \% \text {. Process improvement } \\
\text { reduced the rejection rate. }\end{array}$ \\
\hline $\begin{array}{l}\text { Case } \\
\text { study } 2\end{array}$ & $\begin{array}{l}\text { Bicycle components } \\
\text { chain bush, pin and } \\
\text { outer covering } \\
\text { manufacturing } \\
\text { company }\end{array}$ & $\begin{array}{l}\text { Variations in pin } \\
\text { length, specified is } \\
9.65 \pm 0.5 \mathrm{~mm}\end{array}$ & $\begin{array}{l}\text { Process } \\
\text { improvement }\end{array}$ & $\begin{array}{l}\text { To reduce the pin } \\
\text { rejection which was } \\
8.9 \%\end{array}$ & $\begin{array}{l}\text { Six Sigma } \\
\text { DMAIC } \\
\text { framework }\end{array}$ & $\begin{array}{l}\text { Statistical tools } \\
\text { (Minitab } \\
\text { software, } \\
\text { histogram } \\
\text { analysis) }\end{array}$ & $\begin{array}{l}\text { Defects reduced to } 0.1 \mathrm{ppm} \text {, improved } \\
\text { process and saved energy by } 11 \% \text { by } \\
\text { reducing rework. }\end{array}$ \\
\hline $\begin{array}{l}\text { Case } \\
\text { study } 4\end{array}$ & $\begin{array}{l}\text { Engine components } \\
\text { manufacturing } \\
\text { industry }\end{array}$ & $\begin{array}{l}\text { Component D54T } \\
\text { was not achieving } \\
\text { daily production } \\
\text { plan and had high } \\
\text { rejection rate }\end{array}$ & $\begin{array}{l}\text { Process } \\
\text { improvement }\end{array}$ & $\begin{array}{l}\text { To fulfil daily } \\
\text { production plan to } \\
\text { meet customer } \\
\text { demand. }\end{array}$ & Lean & $\begin{array}{l}\text { (Value stream } \\
\text { Mapping) } \\
\text { Value Stream } \\
\text { Mapping }\end{array}$ & $\begin{array}{l}\text { Removal of wasteful activities, improved } \\
\text { process flow and improved gear quality. }\end{array}$ \\
\hline
\end{tabular}


$8^{\text {th }}$ INTERNATIONAL CONFERENCE ON LEAN SIX SIGMA

\begin{tabular}{|c|c|c|c|c|c|c|c|}
\hline $\begin{array}{l}\text { Key } \\
\text { features }\end{array}$ & $\begin{array}{c}\text { Company } \\
\text { Background }\end{array}$ & Problem & Focus & Objective & Methodology & $\begin{array}{l}\text { Tools and } \\
\text { techniques }\end{array}$ & Results \\
\hline $\begin{array}{l}\text { Case } \\
\text { study } 5\end{array}$ & $\begin{array}{l}\text { A local paper } \\
\text { manufacturing } \\
\text { company }\end{array}$ & $\begin{array}{l}\text { Late paper } \\
\text { delivery, process } \\
\text { inefficiency and } \\
\text { high cost of } \\
\text { production. }\end{array}$ & $\begin{array}{l}\text { Improve } \\
\text { process and } \\
\text { paper quality }\end{array}$ & $\begin{array}{l}\text { Reduce cost, waste } \\
\text { removal and improve } \\
\text { process efficiency }\end{array}$ & $\begin{array}{l}\text { Lean } \\
\text { Six Sigma }\end{array}$ & $\begin{array}{l}\text { DMAIC and } \\
\text { VSM }\end{array}$ & $\begin{array}{l}\text { OEE increased by } 21.6 \% \text { and } 48.45 \% \text {. } \\
\text { Increased process efficiency and reduced } \\
\text { the delivery delays }\end{array}$ \\
\hline $\begin{array}{l}\text { Case } \\
\text { study } 6\end{array}$ & $\begin{array}{l}\text { A Panel } \\
\text { manufacturing } \\
\text { company. }\end{array}$ & $\begin{array}{l}\text { Inaccuracy in cost } \\
\text { forecasting, delays } \\
\text { in delivery and } \\
\text { process } \\
\text { inefficiency. }\end{array}$ & $\begin{array}{l}\text { To improve } \\
\text { process and } \\
\text { increase profit } \\
\text { ratio }\end{array}$ & $\begin{array}{l}\text { Reduce inaccuracy in } \\
\text { cost forecasting, } \\
\text { increase production } \\
\text { and improve process. }\end{array}$ & $\begin{array}{l}\text { Lean } \\
\text { Six Sigma }\end{array}$ & $\begin{array}{l}\text { DMAIC and } \\
\text { VSM }\end{array}$ & $\begin{array}{l}\text { The performance resulted in cost saving of } \\
\text { US } \$ 4,710,262 \text { also the process capabilities } \\
\text { were increased considerably. }\end{array}$ \\
\hline
\end{tabular}

Source (Jirasukprasert, Arturo. Kumar. Ming, Lim, 2014) (Kaushika, Mittalb, Ranac., 2016) (Bhim, Sharma, 200) (Rahani ,Muhammad, 2012) (Mandahawia., Rami, Suleiman, 2012) (Wang, Chen, 2012) 


\subsection{Key features of case studies 1-6}

The case study analysis verified the literature review outcomes that six sigma and lean are both involved with either process or product improvement or both. (Corbett, 2011). As mentioned in the literature that both approaches make use of different tools but gives almost same positive outcomes. (Dahlgaard and Dahlgaard, 2006). Generally, their implementation results in cost reduction and high performance level. (Chiarini, 2013). These factors add up to the profit of an organization. The above table also highlights the differentiating areas of lean and six sigma. Case studies 5 and 6 explains the practical integration of the six sigma and lean methodology in manufacturing organizations. The analysis of these cases would be helpful to comprehend the LSS application model and its outcomes that have been found in literature review.

In case study 6, the involvement of all the staff levels of the organization in LSS implementation proved the aspect, which was highlighted by (Huq, 2006). It showed that an adequate training of the employees is necessary to make a successful LSS implementation. It is the concept of training of Black belts and Master belts which was explained by (Pyzdek, 2009). The strategic elements and the operational elements of the LSS implementation model explained by (Sameh, Khamkham 2016), can be observed clearly, in case study 5 and 6 . The DMAIC framework contributed to the planning and defining of the process steps that covered up the strategic elements of the model and the statistical tools used with lean principles helped to carry out the process operations element.

\subsection{Comparative analysis of Six Sigma and lean}

Based on the literature analysis and evidences collected through case studies the key differences between both of these approaches has been summarized in the following table

Table 2 comparative analysis of Six Sigma and Lean

\begin{tabular}{|c|c|c|}
\hline Parameters & Six Sigma & Lean \\
\hline Origin & The evolution started in Japan and by Motorola & The quality evolution started in Japan and by Toyota. \\
\hline Theory & $\begin{array}{l}\text { Focussed on removal of variations and defects } \\
\text { from the product. }\end{array}$ & $\begin{array}{l}\text { Lean approach highlights areas for the reduction or } \\
\text { removal of wastes. }\end{array}$ \\
\hline Tools & Advanced analytical and statistical tools & Analytical tools \\
\hline Process view & Remove variations and improve process & $\begin{array}{l}\text { It removes waste and improves the process flow. } \\
\text { Helps to reduce the cycle time and helps to achieve } \\
\text { target on time. }\end{array}$ \\
\hline Approach & Quality Management & Project Management \\
\hline Methodologies & $\begin{array}{l}\text { DMAIC (Define, Measure Analyse, Improve } \\
\text { and Control or (verify)) most commonly used }\end{array}$ & $\begin{array}{l}\text { Helps to understand customer demand, customer } \\
\text { value, Value process activities, flow, pull and } \\
\text { perfection }\end{array}$ \\
\hline Primary effect & Helps to reduce cost of production & Helps to reduce lead time/cycle time \\
\hline
\end{tabular}




\begin{tabular}{|l|l|l|}
\hline Secondary effect & Customer satisfaction & $\begin{array}{l}\text { Reduces inventory, increase productivity and } \\
\text { customer satisfaction }\end{array}$ \\
\hline Criticism & Does not involve everyone & Might not be applicable in all types of organizations \\
\hline
\end{tabular}

Source (Andersson, Eriksson, Torstensson, 2009)

\subsection{Lean Six Sigma Implementation Layout}

Keeping in view the case studies analysis under the light of literature findings, it can be interpreted that following aspects are necessary to be added in the LSS implementation framework.

Figure 2 LSS implementation layout

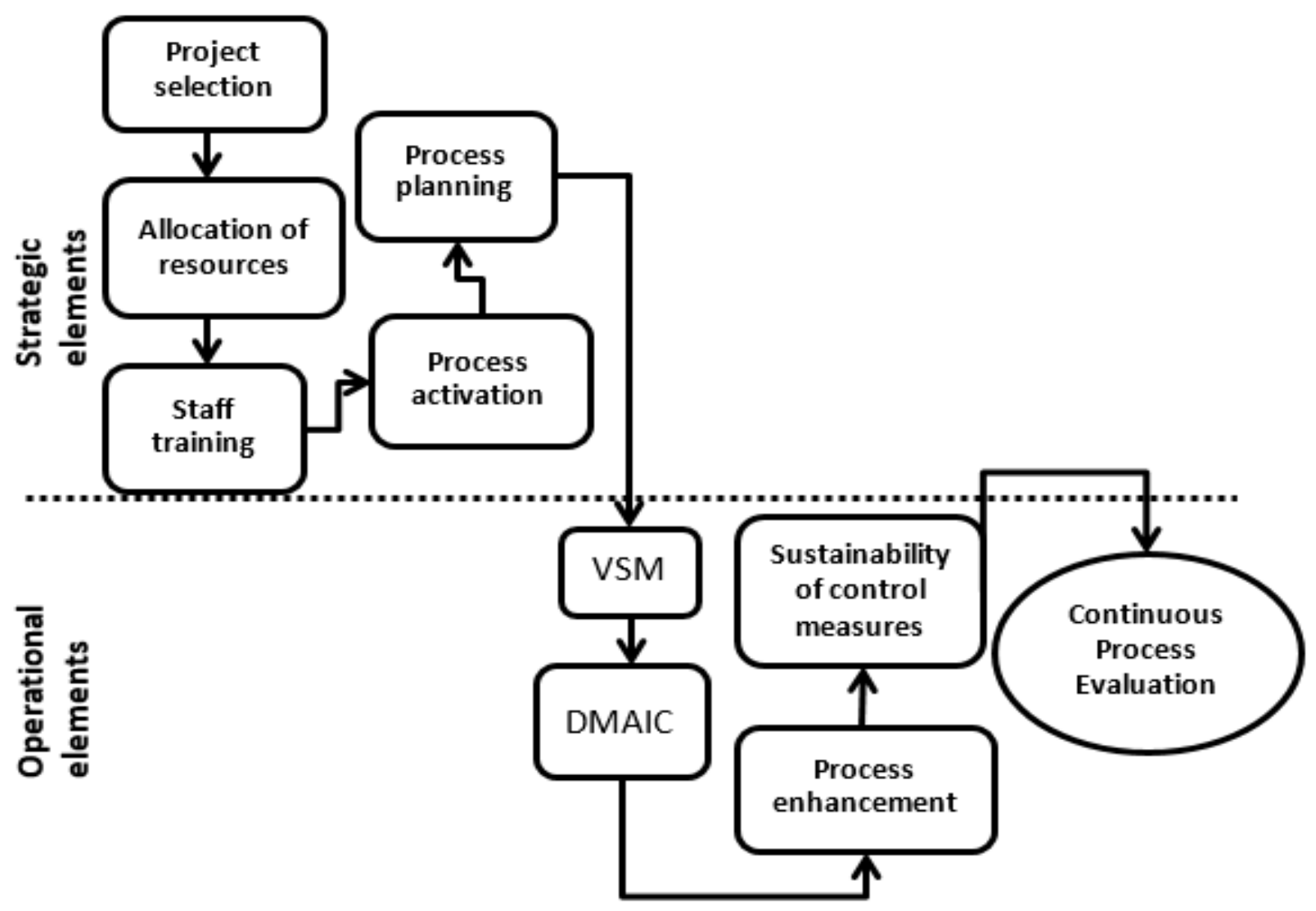




\subsection{Conclusion}

\subsection{Six sigma and Lean in Isolation or their integration?}

The methodology deployed in the case studies reveal that six sigma and Lean approach use different tools for their implementation. For the selection of the either approach, it depends upon the nature of organization and the type of process being carried out.

For example, in case of Thai Gloves manufacturing company, the problem was product oriented and the aim of the company was to remove the variations in the gloves to reduce the rejection ratio. In this case, the integration of lean tools was not necessary because there was no process-associated issue that needed to overcome. Similarly, in second case study, environmental friendly aspect of six sigma has been highlighted. Although in that case the company had a goal to remove the variations in pin length but as a result of reduction of variations (by applying six sigma) company was able to save energy and manpower. The company saved its $11 \%$ of electricity/month which was wasted in doing rework and in making corrections. It is evident that even in this case the ongoing process of manufacturing different components of bicycle was not problematic, there was need to improve product feature. Therefore, the six sigma application was helpful when applied in isolation. On the other hand, the cases explained in context of lean approach, has process improvement focussed goals. As in case of Crankshaft gear, the company was not able to make on time deliveries. There were also unnecessary levels of inventories. So by the implementation of Kanban system a flow of information was run at production line that helped to maintain inventory level as well as on time deliveries. There was no defect in the features of Crankshaft gear that caused the product rejection; therefore, six sigma technique was not required. Similarly, in case of D45T production the company was not able to fulfil the customer order on time. Certain process issues were observed which were affecting the product quality as well. So, to achieve the goals lean methodology was implemented. Value Stream Mapping helped to highlight the focus areas.

The situation presented in last two case studies was different from the previous four. It was observed that in paper manufacturing company aimed to cut short the cost of production along with the increase in Overall Equipment Effectiveness. To achieve this goal company used the six sigma DMAIC framework as a baseline of sequence of project activities and applied the lean principles to remove the wastes within the process that resulted in the increase of OEE by $48.45 \%$ at paper cutting machine. Similarly, in case of Panel Equipment manufacturer, project goal was to increase the cost forecasting accuracy and to improve in the competition of on time deliveries. The integrated LSS provided the opportunity to use the VSM and DMAIC simultaneously. It was helpful for the manufacturer to get to the target area for improvement in the process.

\subsection{Knowledge gaps and future research suggestions}

Literature studies reveal that although Six Sigma and Lean approach are providing positive outcomes in organizations but still the barriers associated with these approaches are directing the project leaders to use the integrated approach. The published data is still lacking behind which can better explain the opportunities availed by implementing LSS and those cannot be obtained through Six Sigma and lean when applied in isolation. Although this approach has been widely used in all type of organizations but the information in literature is necessary to be available so that the strategy of LSS could be well understood and applied. This research 
shall add up to the significance of LSS by highlighting the advantageous prospects of Six Sigma and Lean and then their combination. Adding to this, an effort has been put to trace an effective model for the better implementation of LSS in manufacturing organizations. Keeping in view the barriers of previous suggested frameworks for LSS implementation, a new suggested framework shall be helpful to overcome the barriers at Organizational level

\subsection{References}

Achanga, P. (2006). Critical success factors for lean implementation within SMEs. Journal of Manufacturing Technology Management, 17 (4), 460-71.

Adams, C.W., Gupta, P., \& Wilson Jr., C.E. (2003). Six Sigma deployment, Elsevier Science, Burlington USA.

Andersson,R., Eriksson,H., Torstensson, H. (2006). Similarities and differences between TQM, six sigma and lean. The TQM Magazine, 18(3), $282-296$.

Antony, J. (2006). Six sigma for service processes. Business Process Management, 12(2), 234-48.

Arnheiter, E.D., \& Maleyeff, J. (2005). The integration of lean management and Six Sigma. The TQM Magazine, 17(1), 5-18

Bendell, T. (2006). A review and comparison of six sigma and the lean organisations. The TQM Magazine, 18(3), 255-62.

Bicheno, J. (2004). The New Lean Toolbox towards Fast and Flexible Flow, PICSIE Books, Buckingham.

Brue, G., \& Howes, R. (2006). The McGraw-Hill 36 Hour Course on Six Sigma, McGraw-Hill, New York, NY.

Chakraborty, A. (2006). Applying Six-Sigma in the Service Industry: A Review and Case Study in Call Center Services. Conference: Management of Innovation and Technology, 2

Chen, M., \& Lyu, J. (2009). A Lean Six-Sigma approach to touch panel quality improvement. Production Planning \& Control, 20(5), 445-454.

Chiarini, A. (2013). Differences between Six Sigma applications in manufacturing and the service industry. International Journal of Productivity and Quality Management, 12(3), 345-360.

Čiarnienè, R., \& Vienažindienė, M. (2012). LEAN MANUFACTURING: THEORY AND PRACTICE. ECONOMICS AND MANAGEMENT, 17 (2)

Corbett, L.M. (2011). Lean Six Sigma: the contribution to business excellence. International Journal of Lean Six Sigma, 2 (2), 118-131.

Cross, C. (2007). Business in Special Forces. Industrial Engineer: IE, 39(10), 26-30

Dahlgaard, J.J., \& Dahlgaard, S.M.P. (2001). Lean production, six sigma quality, TQM and company culture - a critical review. Conference Proceedings from the International Shanghai Quality Symposium. 


\section{$8^{\text {th }}$ INTERNATIONAL CONFERENCE ON LEAN SIX SIGMA}

Dahlgaard, J.J., \& Dahlgaard.P. , S.M. (2006). Lean production, six sigma quality, TQM and company culture. The TQM Magazine, 18(3), 263-281.

Ltd Oxford.

Dale, B.G., Wiele, T., \& Iwaarden, J. (2007). Managing Quality. Blackwell Publishing

Doolen, T. (2006). The role of communication and management support in a lean manufacturing implementation. Management Decision, 44, 228-245

Dreachslin, J. (2007). Applying Six Sigma and DMAIC to diversity initiatives. Journal of Healthcare Management, 52(6), 361 -367.

Eckes, G. (2000). The Six Sigma revolution: How General Electric and others turned process into profits. John Wiley, New York.

Ferguson, D. (2007). Lean and six sigma: The same or different? Management Services, 51(3), $12-13$

Folaron, J. (2003). The Evolution of Six Sigma. Six Sigma Forum Magazine, 2(4), 3844

Fornari, A., Maszle, G. (2004) Lean Six Sigma leads Xerox

Froehling, H. (2008). Lean Six Sigma, white paper

George, M., Rowlands, D., \& Kastle, B. (2003). What is Lean Six Sigma? McGrawHill Companies, New York, NY McGrawHill

George, M.L., D. Rowlands, B., \& Kastle. (2004). What is Lean Six Sigma? New York:

Gijo, E.V., Scaria, J., \& Antony, J. (2011) Application of Six Sigma methodology to reduce defects of a grinding process. Quality and Reliability Engineering International.

Godfrey, A.B. (2002). In the beginning. Six Sigma Forum Magazine, 1(3), 46-49.

Hellsten, U., \& Klefsjo, B. (2000). TQM as a management system consisting of values, techniques and tools. TQM Magazine, 12(4), 238-44.

Hopp, W.J., \& Spearman, M.L. (2004). To Pull or not to Pull: What is the Question? Manufacturing \& Service Operations Management, 6(2), 133-148.

Huq, Z. (2006). Six-Sigma implementation through Competency Based Perspective (CBP). Journal of Change Management, 6(3), 277-289.

Jirasukprasert, P., Garza-Reyes, J. A., Kumar, V., \& Lim, M. K. (2014). A Six Sigma and DMAIC application for the reduction of defects in a rubber gloves manufacturing process. International Journal of Lean Six Sigma, 5 (1), 2-21. Indiana!

Kamenski, J.M. (2011). Is Lean Six Sigma “Cool?” Ask Employees of Ft. Wayne,

Kannan, V., \& Tan, K. (2005) Just in time, total quality management, and supply chain management: understanding their linkages and impact on business performance. The International Journal of Management Science, 33(2), 153-62. 


\section{$8^{\text {th }}$ INTERNATIONAL CONFERENCE ON LEAN SIX SIGMA}

Kaushika. P., Mittalb.K. , Ranac.P. (2016). Energy paybacks of six-sigma: A case study of manufacturing industry in India. Management Science Letters.

Mandahawia.N,F., Rami, O., Suleiman. (2012). An Application of Customized Lean Six Sigma to Enhance Productivity at a Paper Manufacturing Company. Jordan Journal of Mechanical and Industrial Engineering, 6.

Monden, Y. (1981). Adaptable kanban system helps Toyota maintain just-in-time production. Industrial Engineering, 13(5), 29.

Monden, Y. (1981). Adaptable kanban system helps Toyota maintain just-in-time production. Industrial Engineering, 13(5), 29.

Motwani, J., Kumar, A., \& Antony, J. (2004). A business process change framework for examining the implementation of Six Sigma: a case study of Dow Chemicals. The TQM Magazine, 16, 273-83

Okoli, C., Schabram, K. (2010). A Guide to Conducting a Systematic Literature Review of Information Systems Research. Sprouts, 10(26).

Omachonu, V. K., \& Ross, J. E. (2004). Principles of total quality. 3rd Edition, CRC Press LLC, Florida.

Pande, P.S., Neuman, R.P., \& Cavanagh, R.R. (2000). The Six Sigma way: How GE, Motorola, and other companies are honing their performance. New York: McGraw-Hill.

Pettersen, J. (2009). Defining Lean Production: Some Conceptual and Practical Issues. The TQM Journal, 21(2), 127-142.

Pyzdek.T., (2009). The Six Sigma Handbook. McGraw-Hill

Rahani, AR., Ashraf, M. (2012). Production Flow Analysis through Value Stream Mapping: A Lean Manufacturing Process Case Study. International Symposium on Robotics and Intelligent Sensors, 41

Sameh., \& Khamkham, M. (2016). Development of Lean Six-Sigma conceptual implementation model for manufacturing organisations. Advances in manufacturing technology XXX, 3, $497-502$.

Sheridan, J.H. (2000). Lean Sigma synergy. Industry Week, 249 (17), 81-2.

Singh, B., Sharma, S.K. (2009). Value stream mapping as a versatile tool for lean implementation: An Indian case study of a manufacturing firm. Measuring Business Excellence, 13(3), $58-68$.

Spear, S. (2004). Learning to lead at Toyota. Harvard Business Review May, 1-9.

Stamatis, D.H. (2004). Six Sigma fundamentals. A complete guide to the system, methods and tools, Productivity Press, New York.

Wang F.k., \& Chen K.S. (2012). Application of Lean Six Sigma to a panel equipment manufacturer. Total Quality Management \& Business Excellence, 23

Wilson, J. (2010). Essentials of Business Research: A Guide to Doing Your Research Project. SAGE Publications, 7 


\section{$8^{\text {th }}$ INTERNATIONAL CONFERENCE ON LEAN SIX SIGMA}

Womack, J. (2002). Lean Thinking; Where Have We Been and Where Are We Going? Forming \& Fabricating. Lean Manufacturing Special Insert, 2.

Womack, J., \& Jones, D.T. (1994). From lean production to the lean enterprise. Harvard Business Review, 72, 93-104.

Womack, J., \& Jones, D.T. (1994). From lean production to the lean enterprise. Harvard Business Review, 72, 93-104. 